Review

\title{
Commonly-used versus less commonly-used methods in the loss of resistance technique for identification of the epidural space: A systematic review and meta-analysis of randomized controlled trials
}

\author{
Larissa Pierri Carvalho a ${ }^{\text {, Arnav Agarwal }}{ }^{\text {b,c }}$, Flávio T. Kashiwagi ${ }^{\mathrm{d}}$, Ione Corrêa ${ }^{\mathrm{e}}$, \\ José Eduardo G. Pereira ${ }^{\mathrm{f}}$, Regina El Dib ${ }^{\mathrm{f}, \mathrm{g}, *}$ \\ a Botucatu Medical School, UNESP - Universidade Estadual Paulista, Botucatu, Brazil \\ b Department of Clinical Epidemiology \& Biostatistics, McMaster University, Hamilton, Ontario, Canada \\ c Faculty of Medicine, University of Toronto, Toronto, Ontario, Canada \\ d Neurology Department, Botucatu Medical School, UNESP - Universidade Estadual Paulista, Botucatu, Brazil \\ e Nursing Department, Botucatu Medical School, UNESP - Universidade Estadual Paulista, Botucatu, Brazil \\ ${ }^{\mathrm{f}}$ Department of Anesthesiology, Botucatu Medical School, UNESP - Universidade Estadual Paulista, Botucatu, Brazil \\ ${ }^{\mathrm{g}}$ McMaster Institute of Urology, McMaster University, St. Joseph's Healthcare, Hamilton, Canada
}

\section{A R T I C L E I N F O}

\section{Article history:}

Received 23 June 2016

Received in revised form 7 January 2017

Accepted 10 January 2017

\section{Keywords:}

Air

Saline

Lidocaine

Epidrum

Acoustic device

Macintosh epidural balloon

Grade

Systematic review

\begin{abstract}
A B S T R A C T
Study objective: To summarize the efficacy of less-commonly used modern methods (e.g. epidrum, lidocaine, acoustic device, Macintosh balloon) compared to more commonly-used methods (i.e. air, saline, both) in the loss of resistance technique for identification of the epidural space.

Design: A systematic review.

Setting: A hospital-affiliated university.

Measurements: The following databases were searched: PubMed, CENTRAL, EMBASE, and LILACS. We used the GRADE approach to rate overall certainty of the evidence.

Results: Eight randomized trials including 1583 participants proved eligible. Results suggested a statistically significantly reduction in inability to locate the epidural space ( $\mathrm{RR} 0.29,95 \% \mathrm{Cl} 0.11,0.77 ; \mathrm{P}=0.01 ; \mathrm{I}^{2}=60 \%$, risk difference (RD) 104/1000, moderate quality evidence), accidental intravascular catheter placement and accidental subarachnoid catheter placement (RR $0.35,95 \% \mathrm{CI} 0.21,0.59 ; \mathrm{P}<0.0001 ; \mathrm{I}^{2}=0 \%$, risk difference (RD) 108 / 1000 , moderate quality evidence), and unblocked segments (RR $0.37,95 \% \mathrm{CI} 0.18,0.77 ; \mathrm{P}=0.008 ; \mathrm{I}^{2}=0 \%$, risk difference (RD) 56/1000, moderate quality evidence) with the use of epidrum, lidocaine, acoustic device, or modified Macintosh epidural balloon methods in comparison to air. Compared to saline, lidocaine presented higher rates of reduction in the inability to locate the epidural space (RR $0.31,95 \% \mathrm{CI} 0.12,0.82 ; \mathrm{P}=0.02$; $\mathrm{I}^{2}=$ not applicable).

Conclusions: Moderate-quality evidence shows that less commonly-used modern methods such as epidrum, lidocaine and acoustic devices, are more efficacious compared to more commonly-used methods (i.e. air, saline, both) in terms of the loss of resistance technique for identification of the epidural space. These findings should be explored further in the context of the clinical practice among anaesthesiologists.
\end{abstract}

(c) 2017 Elsevier Inc. All rights reserved.

\section{Contents}

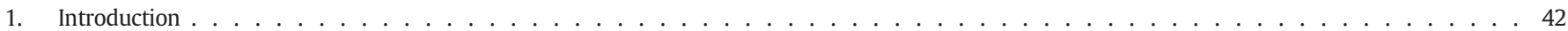

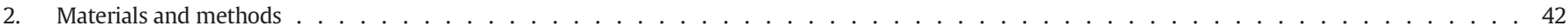

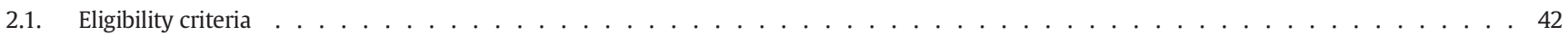

2.2. Data source and searches . . . . . . . . . . . . . . . . . . . . . . . . . . . . . . . . . . 4 43

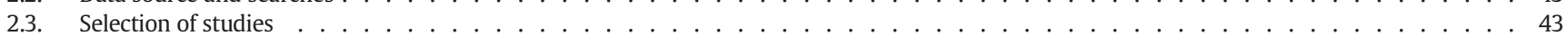

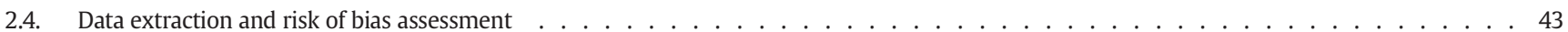

\footnotetext{
* Corresponding author at: Department of Anaesthesiology, Distrito de Rubião Júnior, s/n, Univ Estadual Paulista, Botucatu, São Paulo 18618-970, Brazil.

E-mail address: eldib@fmb.unesp.br (R. El Dib).
} 


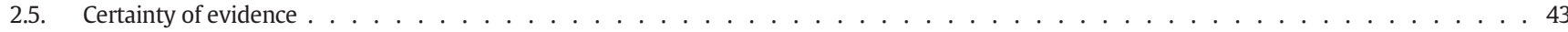

2.6. Data synthesis and statistical analysis . . . . . . . . . . . . . . . . . . . . . . . . . . . . . . 43

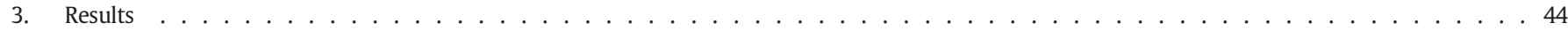

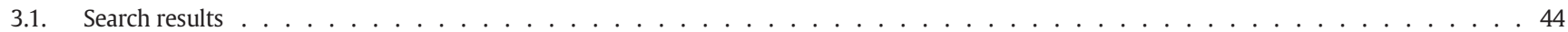

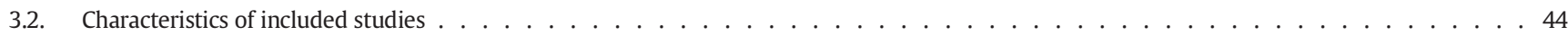

3.3. Risk of bias in individual studies . . . . . . . . . . . . . . . . . . . . . . . . . . . . . . . . 45

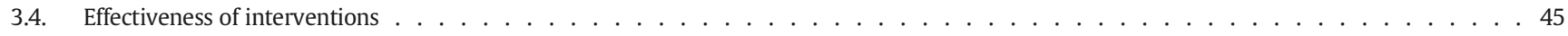

3.4.1. Meta-analysis of inability to locate the epidural space . . . . . . . . . . . . . . . . . . . . . . . . 45

3.4.2. Meta-analysis of accidental intravascular catheter placement and accidental subarachnoid catheter placement . . . . . . . . . 45

3.4.3. Meta-analysis of unblocked segments . . . . . . . . . . . . . . . . . . . . . . . . . . . . 46

3.4.4. Meta-analysis of inadvertent dural puncture . . . . . . . . . . . . . . . . . . . . . . . . . . 46

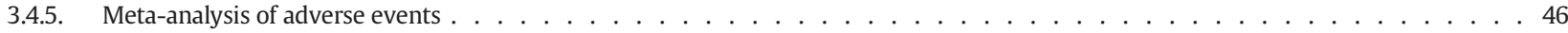

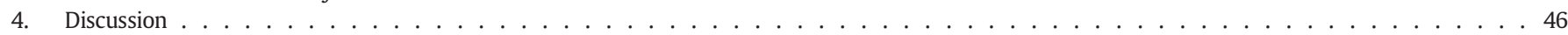

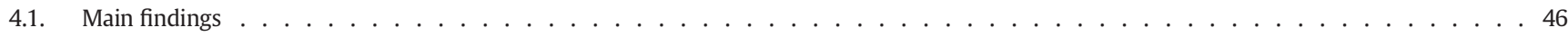

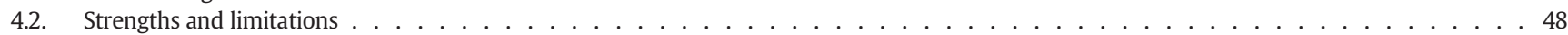

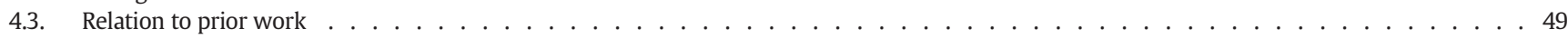

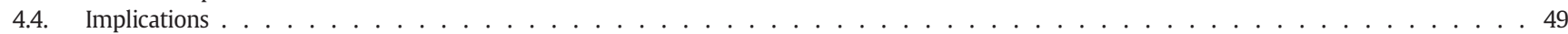

Financial support and sponsorship . . . . . . . . . . . . . . . . . . . . . . . . . . . . . 49

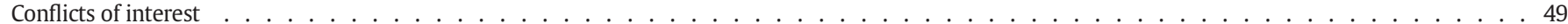

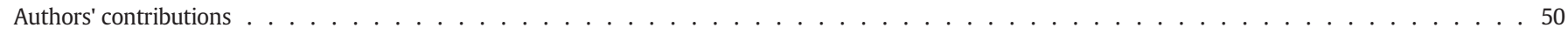

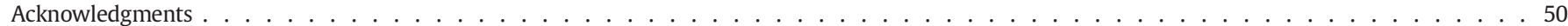

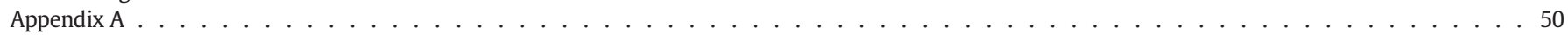

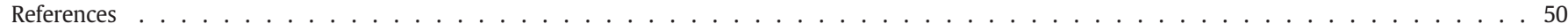

\section{Introduction}

The establishment of epidural anesthesia depends on accurate identification of the epidural space. The loss of resistance (LOR) technique for identification of the epidural space seems to be the most commonly used method for the identification of the epidural space [1,2].

The selection between air and saline in the LOR technique for identification of the epidural space has been headed by know-how and individual preference of anesthesiologists [2,3]. In 1998, a study showed that $53 \%$ of the anesthesiologists interviewed used saline, $37 \%$ used air, $6 \%$ used both, and only $3 \%$ used alternative methods in conducting the LOR technique [2-4].

However, both methods also present disadvantages [3,5,6]. Epidural injection of air implies some hazards [7-11], and air bubbles in the epidural space can result in only partial analgesia [12]. Also, complications may increase with the use of large volumes of air when validation of the correct placement of the epidural needle is needed [13,14]. Furthermore, the use of saline is reported to slow the onset and reduce the quality of epidural analgesia $[15,16]$. Thus, there is no consensus as to whether an air or a liquid medium should be used for identifying the epidural space when using a loss of resistance technique. It is also possible that the techniques not widely used today such as epidrum, Macintosh balloon, advancing needle by indirect means such as hanging drop, or even other liquids such as lidocaine can improve quality of analgesia, and reduce complications associated with loss of resistance technique.

With a variety of methods introduced over the last three decades [2, $17-22]$ to improve the success of the puncture procedure [23,24], the literature remains conflicted in terms of the most appropriate strategy for epidural catheter placement in patients undergoing surgical procedures, women in obstetrical labor and patients with analgesia in the postoperative period.

Over the years, many devices have been designed to improve the success of the puncture procedure [25,26]; however, none of them is widely used today. Among them, there are the epidrum, which is a single-use device that is placed between a luer syringe and epidural needle, and it provides the user with a visual signal when the epidural needle enters the epidural space; the acoustic devices [27]; and the use of lidocaine [28].

In a recent Cochrane systematic review [2], authors concluded that there was no difference between air and saline in the LOR technique for identification of the epidural space; however, the generalizability of these findings might be compromised, given that the majority of the synthesized data was obtained from pregnant women.

The methods used in identification of the epidural space are extremely important for effective anesthesia and to avoid potential complications, such as perforation of the dura mater, epidural hematomas (due to lesions of vessels from the needle and catheter), patchy blocks, low back pain and air venous embolisms [2,29-34].

To the best of our knowledge, a systematic synthesis of randomized controlled trial (RCT) data comparing more commonly-used versus less commonly-used methods in the LOR technique in terms of their efficacy and associated complications has not been conducted. As such, the purpose of this systematic review was to evaluate the efficacy and safety of more commonly-used methods (i.e. air or saline, or both) versus less commonly-used methods (e.g. epidrum, lidocaine, acoustic device, Macintosh balloon) in the LOR technique for identification of the epidural space.

\section{Materials and methods}

The Cochrane Handbook for Intervention Reviews [35] guided our choice of methods. This systematic review of the literature on interventional studies was conducted in accordance with the PRISMA (Preferred Reposting Items for Systematic Reviews and Meta-analysis) statement [36].

\subsection{Eligibility criteria}

We considered all RCTs and quasi-RCTs evaluating one or more commonly-used methods (i.e. air or saline, or both) versus one or more less commonly-used methods, such as epidrum, lidocaine, acoustic device, Macintosh balloon, or the combination of a commonest methods with a not widely used today device (e.g. air and lidocaine), in the LOR technique for identification of the epidural space.

Eligible studies reported one or more of the following: a) inability to locate the epidural space, defined as inability to identify the epidural space and/or unintentional dural puncture by epidural needle; b) accidental intravascular catheter placement and/or accidental subarachnoid catheter placement; c) unblocked segments; d) inadvertent dural puncture; e) adverse events, such as headache or migraine, neck pain, subcutaneous emphysema, difficulty in advancing the catheter, hypotension, 
Table 1

Search strategy for all electronic databases.

(Air OR Na Sodium Chloride OR NaCl Sodium Chloride OR Saline Solution OR Saline OR Epidrum OR 2-2EtN-2MePhAcN OR Lignocaine OR

2-(Diethylamino)- $N$-(2,6-Dimethylphenyl)Acetamide OR Lidocaine Carbonate (2:1) OR Lidocaine Carbonate OR Lidocaine Hydrocarbonate OR Lidocaine Hydrochloride OR Lidocaine Monohydrochloride OR Lidocaine Monoacetate OR Xyloneural OR Strathmann Brand of Lidocaine Hydrochloride OR Lidocaine Sulfate (1:1) OR Octocaine OR Novocol Brand of Lidocaine Hydrochloride OR Xylesthesin OR Xylocaine OR Astrazeneca Brand of Lidocaine OR Xylocitin OR Jenapharm Brand of Lidocanine Hydrochloride OR Dalcaine OR Monohydrate Lidocaine Monohydrochloride OR Acoustic device OR acoustic devices) AND (Epidural analgesia OR epidural anaesthesia OR Peridural Anesthesia OR Extradural Anesthesia OR Epidural Spaces OR Epidural Space)

*Restricted to humans and clinical trials.

paresthesia, dysesthesia, and catheter replacement and/or reposition; and f) pain relief.

Systematic reviews of eligible RCTs and quasi-RCTs were included for the identification of eligible studies through a review of reference lists. Animal studies, case reports and narrative review articles were excluded.

\subsection{Data source and searches}

The search was performed in the following electronic databases: Cochrane Database of Clinical Trials (CENTRAL, 2016, issue 4), PubMed (1966-2016), EMBASE (1980-2016), and LILACS (1982-2016). The databases were searched for available published and unpublished studies from inception through to April 21, 2016.

The search was conducted using multiple combinations of the following key words: "air", "saline solution”, “epidrum”, "lidocaine”, "analgesia" and "epidural space" (Table 1). No restrictions were placed on language, year of publication or publication status.

In addition, a manual search of the reference lists of potential primary studies was conducted, and several major anesthesiology journals were hand-searched for additional eligible studies.

\subsection{Selection of studies}

Using pre-standardized screening forms and protocols, teams of two reviewers independently screened all titles and abstracts identified by the literature search, obtained full-text articles of all potentially eligible studies, and evaluated these studies for eligibility. Reviewers resolved disagreement through discussion, with third party adjudication if necessary.

\subsection{Data extraction and risk of bias assessment}

Three pairs of reviewers independently extracted the following data using a pre-standardized data extraction form: characteristics of the study design; participants; interventions; outcomes event rates and follow-up. Authors of eligible studies were contacted by reviewers to identify missing data and confirm data accuracy of eligible studies.

Reviewers independently assessed risk of bias by using a modified version of the Cochrane Collaboration's tool [37] examining nine domains: adequacy of sequence generation, allocation sequence concealment, blinding of participants and caregivers, blinding of data collectors, blinding for outcome assessment, blinding of data analysts, incomplete outcome data, selective outcome reporting, and the presence of other potential sources of bias not accounted for in previously cited domains [38]. For incomplete outcome data, we considered loss to follow-up of $<10 \%$ and a difference of $<5 \%$ in missing data between intervention and control groups as low risk of bias.

\subsection{Certainty of evidence}

The reviewers used the Grading of Recommendations Assessment, Development and Evaluation (GRADE) methodology to rate certainty of evidence for each outcome as high, moderate, low, or very low [39]. Detailed GRADE guidance was used to assess overall risk of bias [40], imprecision [41], inconsistency [42], indirectness [43] and publication bias [44], and results were summarized in an evidence profile.

\subsection{Data synthesis and statistical analysis}

We calculated pooled risk ratios (RRs) for dichotomous outcomes with the associated 95\% CIs using random-effects models with the Mantel-Haenszel statistical method. We addressed variability in results across studies by using $\mathrm{I}^{2}$ statistic and the P value obtained from the Cochran chi square test. Our primary analyses were based on eligible patients who had reported outcomes for each study (complete case analysis).

We performed subgroup analyses according to the different methods: combination techniques (air and lidocaine) versus air; not widely used today techniques versus commonest methods (saline,

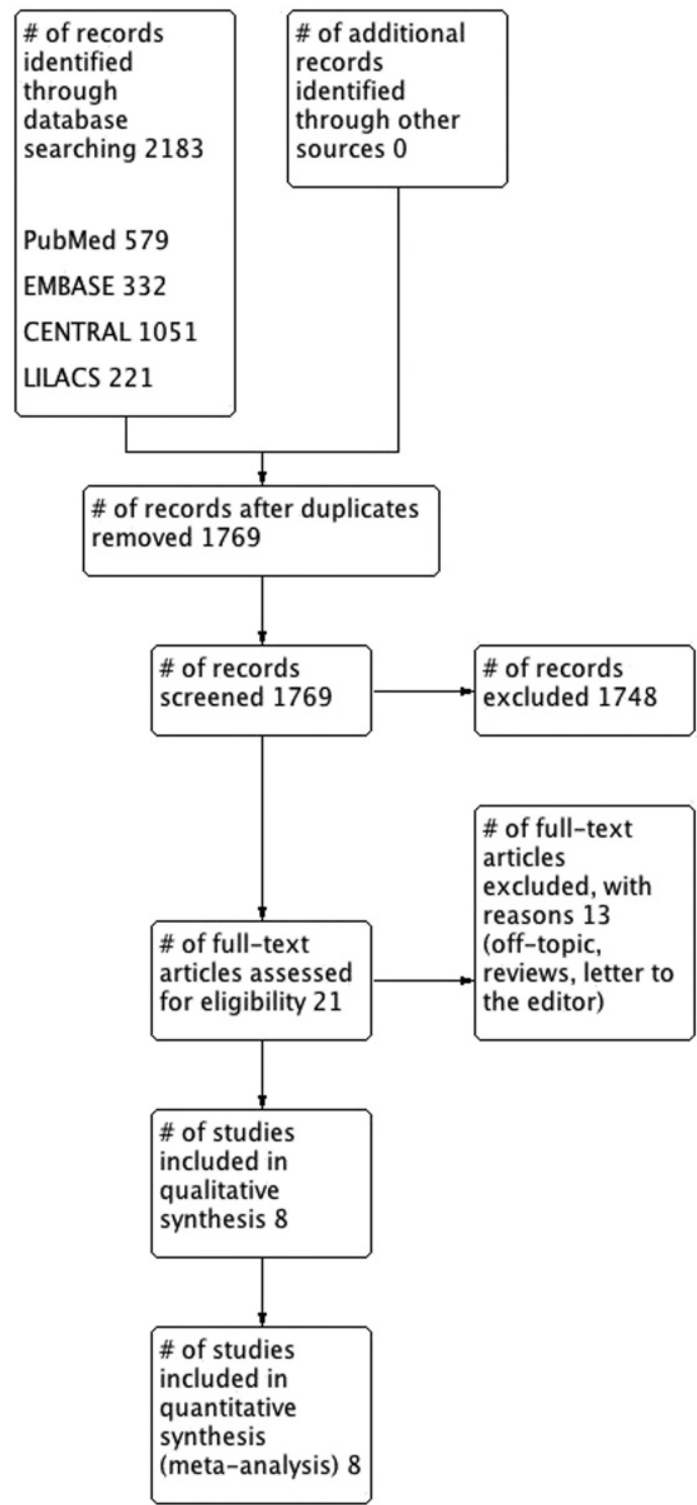

Fig. 1. PRISMA diagram of included studies. 
air); or one type of widely used today techniques versus another. We planned to perform separate analyses for comparisons with different populations consisting of pregnant and non-pregnant patients. We planned to assess publication bias through visual inspection of funnel plots for outcomes addressed in 10 or more studies. We used Review Manager (RevMan) (version 5.3; Nordic Cochrane Centre, Cochrane) for all analyses [45].

\section{Results}

\subsection{Search results}

Following the removal of duplicate hits, we identified a total of 1769 unique citations through database searches. Title and abstract screening was conducted, leaving 21 potentially-eligible citations for which fulltext articles were obtained and reviewed in duplicate. Fourteen studies were excluded, as they were reviews, letters to the editor, or did not address one or more aspects of the research question. A total of eight studies [20,28,46-51] with a total of 1583 participants were deemed eligible for inclusion. No additional eligible studies were identified based on hand-searching of major anesthesia journals or manual review of reference lists of relevant primary studies and systematic reviews (Fig. 1).

\subsection{Characteristics of included studies}

Table 2 describes study characteristics regarding setting, number of participants, mean age, gender, eligibility criteria, and follow-up. All included studies $[20,28,46-51]$ were parallel trials. Three studies $[20,47$,

Table 2

Study characteristics related to setting, number of participants, mean age, gender, inclusion and exclusion criteria, and follow-up.

\begin{tabular}{|c|c|c|c|c|c|c|c|}
\hline Author, year & Location & $\begin{array}{l}\text { No. }^{\text {a }} \\
\text { participants }\end{array}$ & Mean age & $\begin{array}{l}\text { No. } \\
\text { male } \\
(\%)\end{array}$ & Inclusion criteria & Exclusion criteria & Follow-up \\
\hline $\begin{array}{l}\text { Deigahn } 2015 \\
\text { [46] }\end{array}$ & Ireland & 300 & $\begin{array}{l}\text { Epidrum: } \\
\text { not reported } \\
\text { LOR: not } \\
\text { reported }\end{array}$ & $\begin{array}{l}0 \\
0\end{array}$ & $\begin{array}{l}\text { Parturient requesting epidural analgesia } \\
\text { for labor }\end{array}$ & $\begin{array}{l}\text { Patients younger than } 18 \text { or those unable to } \\
\text { give informed consent }\end{array}$ & $24-48 \mathrm{~h}$ \\
\hline Kim 2012 [47] & Korea & 108 & $\begin{array}{l}\text { Epidrum }{ }^{\text {b: }} \\
45 \\
\text { LOR (air, } \\
\text { saline or } \\
\text { both): } 45.4\end{array}$ & $\begin{array}{l}27.7 \\
29.6\end{array}$ & $\begin{array}{l}\text { Patients between } 17 \text { and } 68 \text { years ASA } \\
\text { physical status I or II who were scheduled } \\
\text { for elective gynecologic or orthopedic } \\
\text { surgery under combined spinal-epidural } \\
\text { anesthesia }\end{array}$ & $\begin{array}{l}\text { Patients with contraindications for } \\
\text { combined spinal-epidural anesthesia, } \\
\text { including coagulopathy, local skin infection, } \\
\text { and uncorrected hypovolemia }\end{array}$ & Not reported \\
\hline $\begin{array}{l}\text { Sawada } 2012 \\
\quad[20]\end{array}$ & Japan & 80 & $\begin{array}{l}\text { Epidrum }{ }^{\text {b: }} \\
54.3 \\
\text { LOR or the } \\
\text { hanging } \\
\text { drop: } 51.7\end{array}$ & $\begin{array}{l}37.5 \\
40\end{array}$ & $\begin{array}{l}\text { Adult patients ASA I or II between } 22 \text { and } \\
86 \text { years scheduled for elective surgery } \\
\text { under lombar epidural anesthesia }\end{array}$ & $\begin{array}{l}\text { Patients with lumbar spinal disease, known } \\
\text { coagulation disorders or severe obesity } \\
\left(\mathrm{BMI}>35 \mathrm{~kg} / \mathrm{m}^{2}\right)\end{array}$ & Not reported \\
\hline $\begin{array}{l}\text { Hirabayashi } \\
2011[48]\end{array}$ & Japan & 40 & $\begin{array}{l}\text { Epidrum }{ }^{\text {b. }} \\
35.0 \\
\text { Saline: } 32.0\end{array}$ & $\begin{array}{l}0 \\
0\end{array}$ & $\begin{array}{l}\text { Healthy parturients (gestation age, } \\
<35 \text { weeks) scheduled for elective } \\
\text { cesarean section under combined spinal- } \\
\text { epidural anesthesia }\end{array}$ & Coagulopathy, deformities in vertebra & Not reported \\
\hline $\begin{array}{l}\text { Fyneface-Ogan } \\
2008 \text { [49] }\end{array}$ & Nigeria & 50 & $\begin{array}{l}\text { Modified } \\
\text { Macintosh } \\
\text { epidural } \\
\text { balloon } \\
\text { (Vygon): } \\
29.2 \\
\text { Air: } 30.08\end{array}$ & 0 & $\begin{array}{l}\text { Parturient requesting epidural analgesia } \\
\text { for labor, ASA Class I-II }\end{array}$ & $\begin{array}{l}\text { Patients with ASA physical status II or } \\
\text { greater, pre-eclampsia/eclampsia, morbid } \\
\text { obesity (blood mass index }>35 \mathrm{~kg} / \mathrm{m}^{2} \text { ), a } \\
\text { history of drug or alcohol abuse, heavy } \\
\text { smoking or abnormal liver, hepatic, or } \\
\text { hematological test results. Also were } \\
\text { excluded if clinicians suspected accidental } \\
\text { dural puncture or catheterization of a blood } \\
\text { vessel }\end{array}$ & $\begin{array}{l}1 \mathrm{~h} \text { after epidural } \\
\text { catheter insertion } \\
\text { and at the second } \\
\text { stage of labor }\end{array}$ \\
\hline $\begin{array}{l}\text { Elhakim } 2006 \\
\text { [50] }\end{array}$ & Egypt & 440 & $\begin{array}{l}\text { Acoustic } \\
\text { Device: } 27.3 \\
\text { Air: } 26.8\end{array}$ & $\begin{array}{l}0 \\
0\end{array}$ & $\begin{array}{l}\text { Laboring ASA status } 1 \text { or } 2 \text { woman with } \\
\text { cephalic presentation pregnancy at term } \\
\text { and who requested epidural analgesia }\end{array}$ & $\begin{array}{l}\text { Patients with known coagulation, liver, and } \\
\text { neuromuscular disorders, history of spinal } \\
\text { surgery or trauma, hypersensitivity to amide } \\
\text { local anesthetics, morbid obesity } \\
\left(\mathrm{BMI}>35 \mathrm{~kg} / \mathrm{m}^{2}\right) \text {, and skin lesions at the } \\
\text { site of lumbar puncture }\end{array}$ & Not reported \\
\hline $\begin{array}{l}\text { Evron } 2004 \\
\quad[28]\end{array}$ & $\begin{array}{l}\text { Not } \\
\text { reported }\end{array}$ & 547 & $\begin{array}{l}\text { Lidocaine } \\
3 \mathrm{ml} 2 \% \text { : } \\
28.0 \\
\text { Air: } 28.0 \\
\text { Sequential } \\
\text { use of air } \\
\text { and } \\
\text { lidocaine: }\end{array}$ & $\begin{array}{l}0 \\
0\end{array}$ & $\begin{array}{l}\text { Nulliparous laboring ASA status I and II } \\
\text { women with singketin ceohakic } \\
\text { presentation at term and who requested } \\
\text { epidural analgesia }\end{array}$ & $\begin{array}{l}\text { ASA physical status III or greater, } \\
\text { preemclampsia, morbid obesity (body mass } \\
\text { index }>35 \mathrm{~kg} / \mathrm{m}^{2} \text { ), a history of drug or } \\
\text { alcohol abuse, heavy smoking, or abnormal } \\
\text { liver, hepatic, or hematological test results }\end{array}$ & $\begin{array}{l}1 \mathrm{~h} \text { after epidural } \\
\text { catheter insertion } \\
\text { and at the second } \\
\text { stage of labor }\end{array}$ \\
\hline $\begin{array}{l}\text { Rolbin } 1990 \\
\quad[51]\end{array}$ & Canada & 200 & $\begin{array}{l}27.0 \\
\text { Lidocaine } \\
3 \mathrm{ml}, 1,5 \% \text { : } \\
\text { not reported } \\
\text { No fluid } \\
\text { (air): not } \\
\text { reported } \\
\text { Normal } \\
\text { saline, } 3 \mathrm{ml} \text { : } \\
\text { not reported }\end{array}$ & 0 & $\begin{array}{l}\text { Patients in labor requesting epidural } \\
\text { anesthesia for the first stage of labor }\end{array}$ & Not reported & $\begin{array}{l}20 \text { min after the } \\
\text { insertion of the } \\
\text { epidural needle } \\
\text { and within } 24 \text { h of } \\
\text { delivery }\end{array}$ \\
\hline
\end{tabular}

No.: number; RCT: randomized controlled trial; ml: milliliter; LOR: loss of resistance.

a Randomized participants.

b Epidrum: is $2.5-2 \mathrm{~cm}$ in size and consists of a hard plastic body chamber, an injection port with a one way valve, an outlet port to connect to the epidural needle, and a soft, thin silicon membrane diaphragm on top of the device. 
48] were conducted largely in Asia (one in Korea, and two in Japan), one in Ireland [46], one in Egypt [50], one in Canada [51], and one in Nigeria [49]. Evron et al. 2004 did not report the setting of their study [28]. Trial sample sizes ranged from 40 participants [48] to 547 participants [28]. Participants were typically females between the ages of 20 and 60 years. Studies followed participants from $20 \mathrm{~min}$ [51] to $48 \mathrm{~h} \mathrm{[46]}$ post-needle insertion (Table 2).

Table 3 describes study characteristics related to intervention and comparator groups, and assessed outcomes. Of the eight RCTs, three compared epidrum to air $[20,46,47]$; two compared epidrum to saline $[47,48]$; one compared modified Macintosh epidural balloon to air [49]; one compared acoustic device to air; one compared lidocaine $2 \%$ to air [28]; one compared lidocaine $1.5 \%$ to air or saline [51]; and one compared the acoustic device to air [50] (Table 3).

\subsection{Risk of bias in individual studies}

Fig. 2 and Table 4 describe the risk of bias assessment for the RCTs. Allocation concealment was a major risk of bias limitation across all eligible RCTs [20,28,46-51]. Other issues with risk of bias among eligible RCTs were random sequence generation [20,28,47-51], lack of blinding of participants, caregivers, data collectors, and statisticians [20,28,4749,51], and lack of blinding of outcome assessors [20,47-49,51].

We considered the Fyneface-Ogan 2008 study [49] as high risk of bias for blinding of outcome assessors, because although authors reported that there was a blinded anaesthetist that assessed some outcomes such as the existence of unblocked segments and the extent of sensory blockade, an attending anaesthetist that was not blinded noted paraesthesia during insertion of the catheter, inability to advance the catheter, and intravenous or subarachnoid cannulation (Fig. 2, Table 4).

\subsection{Effectiveness of interventions}

\subsubsection{Meta-analysis of inability to locate the epidural space}

Results from seven RCTs [20,28,46-47,49-51] suggested a statistically significantly reduction in inability to locate the epidural space using epidrum, lidocaine, acoustic device, or modified Macintosh epidural balloon over air, or hanging drop (RR 0.29, 95\% CI 0.11, 0.77; P = $0.01 ; I^{2}=60 \%$, risk difference (RD) $104 / 1000$, moderate quality evidence) (Fig. 3, Table 5). A plausible sensitivity analysis without the Deighan et al. 2015 study [46] yielded results that were consistent with the primary analysis, decreasing the inconsistency among plotted studies and suggesting an even higher reduction in inability to locate the epidural space with less commonly-used methods in comparison to air or the hanging drop ( $\mathrm{RR} 0.23,95 \% \mathrm{CI} 0.11,0.49 ; \mathrm{P}=0.0001$; $\mathrm{I}^{2}=36 \%$ ) (Appendix Fig. 1). Certainty in evidence was rated down to moderate because of inconsistency and risk of bias due to allocation concealment limitations across all studies, and lack of blinding of participants, caregivers, data collectors, statisticians [20,28,47,49,51] and outcome assessors [20,47-49,51] (Fig. 2, Table 5).

Results from a single study [28] also suggested a statistically significantly reduction in inability to locate the epidural space with the use of combination methods (i.e. air and lidocaine) over air (RR $0.20,95 \% \mathrm{CI}$ $0.09,0.48 ; \mathrm{P}=0.0003 ; \mathrm{I}^{2}=$ not applicable) (Fig. 3). Additional results related to a subgroup meta-analysis comparing less commonly-used techniques versus saline also found also a statistically significance difference favouring the use of lidocaine (RR 0.31, 95\% CI 0.12, 0.82; P = $0.02 ; \mathrm{I}^{2}=$ not applicable) (Fig. 3 ).

\subsubsection{Meta-analysis of accidental intravascular catheter placement and ac-} cidental subarachnoid catheter placement

Results from two RCTs $[28,50]$ suggested a statistically significantly reduction in accidental intravascular catheter placement and accidental subarachnoid catheter placement with the use of lidocaine or acoustic device over air (RR 0.35, 95\% CI 0.21, 0.59; P $<0.0001 ; \mathrm{I}^{2}=0 \%, \mathrm{RD}$ 108/1000, moderate quality evidence) (Fig. 4; Table 5). Certainty in evidence was rated down to moderate because of risk of bias due to lack of blinding of participants, caregivers, data collectors, statistician [27], and allocation concealment [48] (Fig. 2, Table 5).

Results from a single study [28] also suggested a statistically significantly reduction in accidental intravascular catheter placement and/or accidental subarachnoid catheter placement with the use of combination methods (air and lidocaine) over air (RR 0.46, 95\% CI 0.25, 0.84; $\mathrm{P}=0.01 ; \mathrm{I}^{2}=$ not applicable) (Fig. 4).

Table 3

Study characteristics related to the description of intervention, control group, and assessed outcomes.

\begin{tabular}{|c|c|c|c|}
\hline Author, year & $\begin{array}{l}\text { Description of intervention } \\
\text { group (randomized patients, } \\
\text { n) }\end{array}$ & $\begin{array}{l}\text { Description of control } \\
\text { groups (randomized } \\
\text { patients, } \mathrm{n} \text { ) }\end{array}$ & Measured outcomes \\
\hline $\begin{array}{l}\text { Deighan } 2015 \\
\text { [46] }\end{array}$ & Epidrum $(\mathrm{n}=150)$ & $\begin{array}{l}\text { LOR (not specified) } \\
(\mathrm{n}=150)\end{array}$ & $\begin{array}{l}\text { Dural puncture; number of attempts taken to site epidural; failure (defined as being unable to } \\
\text { site the epidural catheter after three attempts) to site epidural requiring a second operator; } \\
\text { and failure of epidural analgesia (defined as failure to obtain a sensory block after initial local } \\
\text { anaesthetic loading dose, resulting in the epidural catheter being re-sited). }\end{array}$ \\
\hline Kim 2012 [47] & Epidrum $^{\mathrm{a}}(\mathrm{n}=54)$ & $\begin{array}{l}\text { LOR (air, saline or both) } \\
(\mathrm{n}=54)\end{array}$ & $\begin{array}{l}\text { Failure; time; epidural depth (cm, L3-4 and L4-5 interspace); dural puncture; ease score of } \\
\text { identification (operator and observer); and satisfaction score of operator. }\end{array}$ \\
\hline $\begin{array}{l}\text { Sawada } 2012 \\
\text { [20] }\end{array}$ & Epidrum $^{\mathrm{a}}(\mathrm{n}=40)$ & $\begin{array}{l}\text { LOR (not specified) or the } \\
\text { hanging drop }(n=40)\end{array}$ & $\begin{array}{l}\text { Epidural catheterization; clinical effects of epidural anesthesia; accidental dural puncture; and } \\
\text { time to identify epidural space. }\end{array}$ \\
\hline $\begin{array}{r}\text { Hirabayashi } \\
2011[48]\end{array}$ & Epidrum $^{\mathrm{a}}(\mathrm{n}=20)$ & Saline $(\mathrm{n}=20)$ & $\begin{array}{l}\text { Inability to locate the epidural space; accidental intravascular catheter placement and/or } \\
\text { accidental subarachnoid catheter placement; inadvertent dural puncture; and morbidities. }\end{array}$ \\
\hline $\begin{array}{l}\text { Fyneface-Ogan } \\
2008[49]\end{array}$ & $\begin{array}{l}\text { Modified Macintosh epidural } \\
\text { balloon }(\text { Vygon } \circledast)(n=25)\end{array}$ & $\operatorname{Air}(n=25)$ & $\begin{array}{l}\text { Easy of epidural identification; accidental dural puncture; quality of block; post-dural } \\
\text { puncture headache; delay in second stage; shivering. }\end{array}$ \\
\hline $\begin{array}{l}\text { Elhakim } 2006 \\
\text { [50] }\end{array}$ & Acoustic device $(n=220)$ & $\operatorname{Air}(n=220)$ & $\begin{array}{l}\text { Side effects and complications of epidural analgesia defined as difficult epidural catheter } \\
\text { insertion; patients with unblocked; accidental intravascular catheter; accidental dural } \\
\text { puncture; postural headache; hypotension; postpartum urinary retention; transient } \\
\text { neurological deficit; persistent neurological deficit; and characteristics of epidural analgesia. }\end{array}$ \\
\hline $\begin{array}{l}\text { Evron } 2004 \\
\quad[28]\end{array}$ & Lidocaine $3 \mathrm{ml}, 2 \%(\mathrm{n}=185)$ & $\begin{array}{l}\text { Air }(\mathrm{n}=180) \\
\text { Air and lidocaine }(\mathrm{n}=182)\end{array}$ & $\begin{array}{l}\text { Side effects and complications of epidural anesthesia defined as difficult epidural catheter } \\
\text { insertion; accidental intravascular catheter placement; patients with unblocked segments; } \\
\text { accidental dural puncture; postdural puncture headache; transient neurological deficit; } \\
\text { persistent neurological deficit; postpartum urinary retention; hypotension and; } \\
\text { characteristics of epidural analgesia. }\end{array}$ \\
\hline $\begin{array}{l}\text { Rolbin } 1990 \\
\text { [51] }\end{array}$ & Lidocaine $3 \mathrm{ml}, 1.5 \%(\mathrm{n}=68)$ & $\begin{array}{l}\text { Air }(\mathrm{n}=77) \\
\text { Saline } 3 \mathrm{ml}(\mathrm{n}=55)\end{array}$ & $\begin{array}{l}\text { Complications of the catheter insertion such as blood in catheter; paresthesiae; involuntary } \\
\text { movement; threaded easily (inability to locate epidural space); and pain relief. }\end{array}$ \\
\hline
\end{tabular}

$\mathrm{n}$ : number; $\mathrm{cm}$ : centimeters; $\mathrm{ml}$ : milliliters; LOR: Loss of resistance technique.

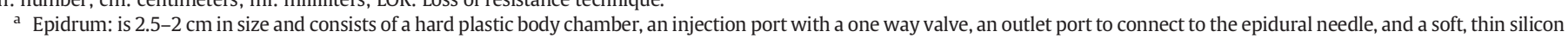
membrane diaphragm on top of the device. 


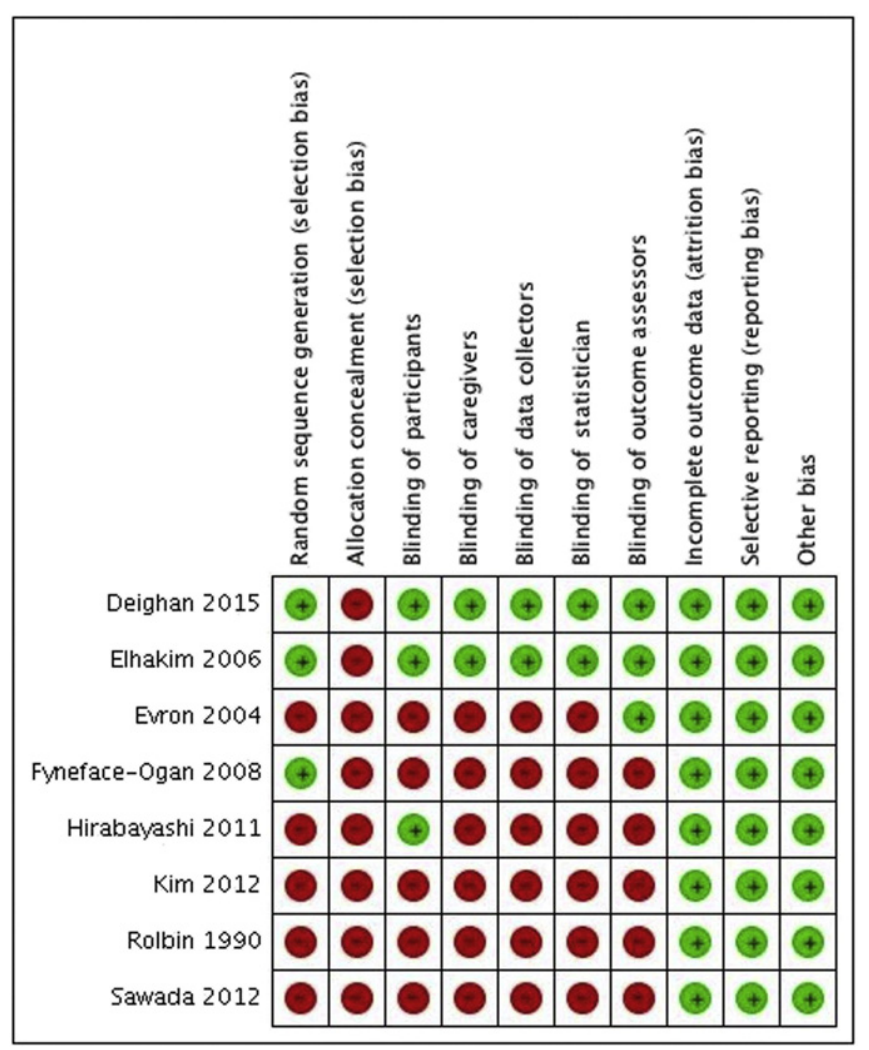

Fig. 2. Risk of bias in individual studies. Note: "probably yes" is grouped into "yes", and "probably no" is grouped into "no".

\subsubsection{Meta-analysis of unblocked segments}

Results from three RCTs $[28,49,50]$ suggested a statistically significantly reduction of unblocked segments with the use of lidocaine, acoustic device, or modified Macintosh epidural balloon over air (RR 0.37, 95\% CI 0.18, 0.77; P = 0.008; $\mathrm{I}^{2}=0 \%$, RD 56/ 1000 , moderate quality evidence) (Fig. 5, Table 5). Certainty in evidence was rated down to moderate because of risk of bias due to lack of blinding of participants, caregivers, data collectors and statisticians [28,49], and allocation concealment [49,50] (Fig. 2, Table 5).
Results from a single study [28] comparing combination methods (air and lidocaine) versus air found no statistically significance difference (RR 0.33, 95\% CI 0.11, 1.00; P = 0.05; $\mathrm{I}^{2}=$ not applicable) (Fig. 5).

\subsubsection{Meta-analysis of inadvertent dural puncture}

Results from six RCTs [20,28,46,49-50] found no statistically significance difference related to inadvertent dural puncture comparing epidrum, lidocaine, acoustic device, or modified Macintosh epidural balloon versus air (RR 0.27, 95\% CI 0.05, 1.14; P = 0.26; $I^{2}=51 \%$, RD 14/ 1000, low quality evidence) (Fig. 6, Table 5). Certainty in evidence was rated down to low because of inconsistency and risk of bias issues related to allocation concealment limitations across all studies, and lack of blinding of participants, caregivers, data collectors and statisticians $[20,28,47,49]$ and outcome assessors $[20,47,49]$ (Fig. 2, Table 5).

Results from a single study [28] suggested a statistically significantly reduction in the inadvertent dural puncture with the use of combination methods (air and lidocaine) over air (RR 0.02, 95\% CI 0.00, 0.26; $\mathrm{P}=0.004 ; \mathrm{I}^{2}=$ not applicable) (Fig. 6).

\subsubsection{Meta-analysis of adverse events}

Results from three RCTs [49-51] suggested no statistically significant difference related to adverse events with the use of acoustic device, modified Macintosh epidural balloon, or lidocaine versus air (RR 0.56, $95 \%$ CI 0.19, 1.68; P = 0.30; $I^{2}=36 \%$, RD 9/1000, moderate quality evidence) (Fig. 7, Table 5). Certainty in evidence was rated down to moderate because of risk of bias due to lack of blinding of participants, caregivers, data collectors, statisticians, and outcome assessors [35,37], and allocation concealment [49-51] (Fig. 2, Table 5).

Results related to a single study [51] comparing lidocaine versus saline found no statistically significance difference (RR 0.95, 95\% CI 0.67, 1.34; $\mathrm{P}=0.76 ; \mathrm{I}^{2}=$ not applicable) (Fig. 7).

\section{Discussion}

\subsection{Main findings}

Based on pooled data from eight randomized trials with 1583 participants, our systematic review found evidence for a reduction in inability to locate the epidural space, accidental intravascular catheter placement and/or accidental subarachnoid catheter placement, unblocked segments, and inadvertent dural puncture with the use of the less commonly-used methods (i.e. epidrum, lidocaine, acoustic device, or

Table 4

Risk of bias assessment

\begin{tabular}{|c|c|c|c|c|c|c|c|c|c|c|}
\hline Author, year & $\begin{array}{l}\text { Was the } \\
\text { randomization } \\
\text { sequence } \\
\text { adequately } \\
\text { generated? }\end{array}$ & $\begin{array}{l}\text { Was } \\
\text { allocation } \\
\text { adequately } \\
\text { concealed? }\end{array}$ & $\begin{array}{l}\text { Was there } \\
\text { blinding of } \\
\text { participants? }\end{array}$ & $\begin{array}{l}\text { Was there } \\
\text { blinding of } \\
\text { caregivers? }\end{array}$ & $\begin{array}{l}\text { Was there } \\
\text { blinding of } \\
\text { data } \\
\text { collectors? }\end{array}$ & $\begin{array}{l}\text { Was there } \\
\text { blinding of } \\
\text { statistician? }\end{array}$ & $\begin{array}{l}\text { Was there } \\
\text { blinding of } \\
\text { outcome } \\
\text { assessors? }\end{array}$ & $\begin{array}{l}\text { Was loss to } \\
\text { follow-up } \\
\text { (missing } \\
\text { outcome data) } \\
\text { infrequent? }{ }^{\mathrm{a}}\end{array}$ & $\begin{array}{l}\text { Are reports of the } \\
\text { study free of } \\
\text { suggestion of } \\
\text { selective outcome } \\
\text { reporting? }\end{array}$ & $\begin{array}{l}\text { Was the study } \\
\text { apparently free of } \\
\text { other problems that } \\
\text { could put it at a risk } \\
\text { of bias? }\end{array}$ \\
\hline $\begin{array}{l}\text { Deighan } 2015 \\
\text { [46] }\end{array}$ & Definitely yes & $\begin{array}{l}\text { Probably } \\
\text { no }\end{array}$ & Probably yes & $\begin{array}{l}\text { Probably } \\
\text { yes }\end{array}$ & $\begin{array}{l}\text { Probably } \\
\text { yes }\end{array}$ & $\begin{array}{l}\text { Probably } \\
\text { yes }\end{array}$ & $\begin{array}{l}\text { Definitely } \\
\text { yes }\end{array}$ & Definitely yes & Definitely yes & Probably yes \\
\hline Kim 2012 [47] & Probably no & $\begin{array}{l}\text { Probably } \\
\text { no }\end{array}$ & Definitely no & $\begin{array}{l}\text { Definitely } \\
\text { no }\end{array}$ & $\begin{array}{l}\text { Probably } \\
\text { no }\end{array}$ & Probably no & $\begin{array}{l}\text { Probably } \\
\text { no }\end{array}$ & Definitely yes & Definitely yes & Probably yes \\
\hline $\begin{array}{l}\text { Sawada } 2012 \\
\text { [20] }\end{array}$ & Probably no & $\begin{array}{l}\text { Probably } \\
\text { no }\end{array}$ & Probably no & $\begin{array}{l}\text { Probably } \\
\text { no }\end{array}$ & $\begin{array}{l}\text { Definitely } \\
\text { no }\end{array}$ & Probably no & $\begin{array}{l}\text { Probably } \\
\text { no }\end{array}$ & Definitely yes & Definitely yes & Probably yes \\
\hline $\begin{array}{r}\text { Hirabayashi } \\
2011 \text { [48] }\end{array}$ & Probably no & $\begin{array}{l}\text { Probably } \\
\text { no }\end{array}$ & Probably yes & $\begin{array}{l}\text { Definitely } \\
\text { no }\end{array}$ & $\begin{array}{l}\text { Definitely } \\
\text { no }\end{array}$ & Probably no & $\begin{array}{l}\text { Probably } \\
\text { no }\end{array}$ & Definitely yes & Definitely yes & Definitely yes \\
\hline $\begin{array}{c}\text { Fyneface-Ogan } \\
2008 \text { [49] }\end{array}$ & Definitely yes & $\begin{array}{l}\text { Probably } \\
\text { no }\end{array}$ & Probably no & $\begin{array}{l}\text { Definitely } \\
\text { no }\end{array}$ & $\begin{array}{l}\text { Probably } \\
\text { no }\end{array}$ & Probably no & $\begin{array}{l}\text { Definitely } \\
\text { no }\end{array}$ & Definitely yes & Definitely yes & Probably yes \\
\hline $\begin{array}{l}\text { Elhakim } 2006 \\
{[50]}\end{array}$ & Definitely yes & $\begin{array}{l}\text { Probably } \\
\text { no }\end{array}$ & Probably yes & $\begin{array}{l}\text { Probably } \\
\text { yes }\end{array}$ & $\begin{array}{l}\text { Probably } \\
\text { yes }\end{array}$ & $\begin{array}{l}\text { Probably } \\
\text { yes }\end{array}$ & $\begin{array}{l}\text { Definitely } \\
\text { yes }\end{array}$ & Definitely yes & Definitely yes & Probably yes \\
\hline $\begin{array}{l}\text { Evron } 2004 \\
\quad[28]\end{array}$ & Probably no & $\begin{array}{l}\text { Probably } \\
\text { no }\end{array}$ & Probably no & $\begin{array}{l}\text { Probably } \\
\text { no }\end{array}$ & $\begin{array}{l}\text { Probably } \\
\text { no }\end{array}$ & Probably no & $\begin{array}{l}\text { Definitely } \\
\text { yes }\end{array}$ & Definitely yes & Definitely yes & Probably yes \\
\hline $\begin{array}{l}\text { Robin } 1990 \\
{[51]}\end{array}$ & Probably no & $\begin{array}{l}\text { Probably } \\
\text { no }\end{array}$ & Probably no & $\begin{array}{l}\text { Probably } \\
\text { no }\end{array}$ & $\begin{array}{l}\text { Probably } \\
\text { no }\end{array}$ & Probably no & $\begin{array}{l}\text { Probably } \\
\text { no }\end{array}$ & Definitely yes & Definitely yes & Probably yes \\
\hline
\end{tabular}

All answers as: definitely yes (low risk of bias), probably yes, probably no, definitely no (high risk of bias).

a Defined as $<10 \%$ loss to outcome data or difference between groups $<5 \%$ and those excluded are not likely to have made a material difference in the effect observed. 


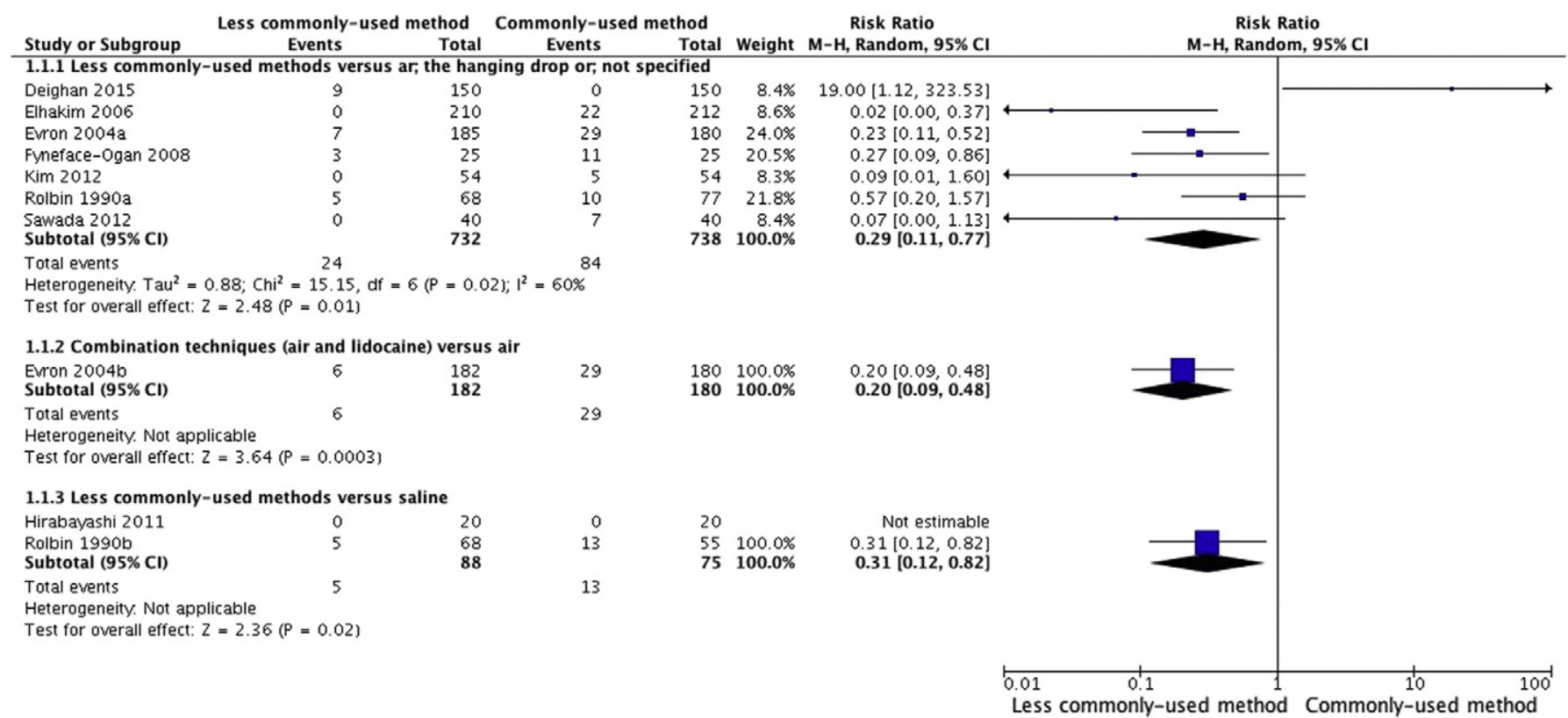

Fig. 3. Meta-analysis of inability to locate the epidural space.

modified Macintosh epidural balloon) relative to more commonly-used (air or saline, or both) (Figs. 3, 4, 5, 6). Moderate quality evidence supports the use of less commonly-used methods in the LOR technique for identification of the epidural space (Table 5). A plausible sensitivity analyses to assess the inconsistency associated with Deighan et al.
2015 study [46] yielded results that were consistent with the primary analysis, and also decreased the heterogeneity among studies plotted in the meta-analysis (Appendix Fig. 1).

A number of factors decreased our certainty in the estimates for inability to locate the epidural space. In particular, issues related to risk

Table 5

GRADE evidence profile: alternative techniques (epidrum, lidocaine, acoustic device, modified Macintosh epidural balloon) versus air for identification of the epidural space.

\begin{tabular}{|c|c|c|c|c|c|c|c|c|c|c|c|}
\hline \multicolumn{6}{|c|}{ Quality assessment } & \multicolumn{5}{|c|}{ Summary of findings } & \multirow{2}{*}{$\begin{array}{l}\text { Certainty in } \\
\text { estimates } \\
\text { OR Quality } \\
\text { of evidence }\end{array}$} \\
\hline $\begin{array}{l}\text { No of } \\
\text { participants } \\
\text { (studies) }\end{array}$ & Risk of bias & Inconsistency & Indirectness & Imprecision & $\begin{array}{l}\text { Publication } \\
\text { bias }\end{array}$ & Conventional & Alternative & $\begin{array}{l}\text { risk }(95 \% \\
\mathrm{CI})\end{array}$ & Conventional & Alternative & \\
\hline \multicolumn{12}{|c|}{ Inability to locate the epidural space } \\
\hline $\begin{array}{l}1470 \\
(7)\end{array}$ & $\begin{array}{l}\text { Serious } \\
\text { limitations }^{a}\end{array}$ & $\begin{array}{l}\text { Serious } \\
\text { limitations }^{b}\end{array}$ & $\begin{array}{l}\text { No serious } \\
\text { limitations }\end{array}$ & $\begin{array}{l}\text { No serious } \\
\text { limitations }\end{array}$ & Undetected & $84 / 738$ & $24 / 732$ & $\begin{array}{l}0.29 \\
(0.11-0.77)\end{array}$ & $\begin{array}{l}104 \text { per } \\
1000^{c}\end{array}$ & $\begin{array}{l}74 \text { fewer per } \\
1000 \\
\text { ( } 93 \text { fewer to } \\
24 \text { fewer) }\end{array}$ & MODERATE \\
\hline \multicolumn{12}{|c|}{ Accidental intravascular catheter placement and/or accidental subarachnoid catheter placement } \\
\hline $\begin{array}{l}787 \\
(2)\end{array}$ & $\begin{array}{l}\text { Serious } \\
\text { limitations }^{\mathrm{a}}\end{array}$ & $\begin{array}{l}\text { No serious } \\
\text { limitations }\end{array}$ & $\begin{array}{l}\text { No serious } \\
\text { limitations }\end{array}$ & $\begin{array}{l}\text { No serious } \\
\text { limitations }\end{array}$ & Undetected & $53 / 392$ & $19 / 395$ & $\begin{array}{l}0.35 \\
(0.21-0.59)\end{array}$ & $\begin{array}{l}108 \text { per } \\
1000^{C}\end{array}$ & $\begin{array}{l}71 \text { fewer per } \\
1000 \\
\text { ( } 86 \text { fewer to } \\
45 \text { fewer) }\end{array}$ & MODERATE \\
\hline \multicolumn{12}{|c|}{ Unblocked segments } \\
\hline $\begin{array}{l}787 \\
(2)\end{array}$ & $\begin{array}{l}\text { Serious } \\
\text { limitations }^{\mathrm{a}}\end{array}$ & $\begin{array}{l}\text { No serious } \\
\text { limitations }\end{array}$ & $\begin{array}{l}\text { No serious } \\
\text { limitations }\end{array}$ & $\begin{array}{l}\text { No serious } \\
\text { limitations }\end{array}$ & Undetected & $24 / 392$ & $9 / 395$ & $\begin{array}{l}0.38 \\
(0.18-0.82)\end{array}$ & 56 per $1000^{c}$ & $\begin{array}{l}35 \text { fewer per } \\
1000 \\
\text { ( } 46 \text { fewer to } \\
11 \text { fewer) }\end{array}$ & MODERATE \\
\hline \multicolumn{12}{|c|}{ Inadvertent dural puncture } \\
\hline $\begin{array}{l}1325 \\
(6)\end{array}$ & $\begin{array}{l}\text { Serious } \\
\text { limitations }^{\mathrm{a}}\end{array}$ & $\begin{array}{l}\text { Serious } \\
\text { limitations }^{\mathrm{b}}\end{array}$ & $\begin{array}{l}\text { No serious } \\
\text { limitations }\end{array}$ & $\begin{array}{l}\text { Serious } \\
\text { imprecision }^{d}\end{array}$ & Undetected & $37 / 661$ & $4 / 664$ & $\begin{array}{l}0.27 \\
(0.05-1.56)\end{array}$ & 14 per $1000^{c}$ & $\begin{array}{l}10 \text { fewer per } \\
1000 \\
(13 \text { fewer to } \\
8 \text { more) }\end{array}$ & LOW \\
\hline \multicolumn{12}{|c|}{ Adverse events } \\
\hline $\begin{array}{l}617 \\
(3)\end{array}$ & $\begin{array}{l}\text { Serious } \\
\text { limitations }^{a}\end{array}$ & $\begin{array}{l}\text { No serious } \\
\text { limitations }\end{array}$ & $\begin{array}{l}\text { No serious } \\
\text { limitations }\end{array}$ & $\begin{array}{l}\text { Serious } \\
\text { imprecision }^{d}\end{array}$ & Undetected & $50 / 314$ & $35 / 303$ & $\begin{array}{l}0.56 \\
(0.19-1.68)\end{array}$ & 9 per $1000^{c}$ & $\begin{array}{l}4 \text { fewer per } \\
1000 \\
\text { ( } 7 \text { fewer to } \\
6 \text { more) }\end{array}$ & MODERATE \\
\hline
\end{tabular}

a The large sample of studies include many that were ranked as high risk of bias in some of the categories analyzed.

b There was some heterogeneity among included studies.

c Baseline risk estimates for inability to locate the epidural space come from control arm of Elhakim 2006 [50] study (largest randomized trial in the meta-analysis).

d $95 \% \mathrm{CI}$ for absolute effects include clinically important benefit and no benefit. 


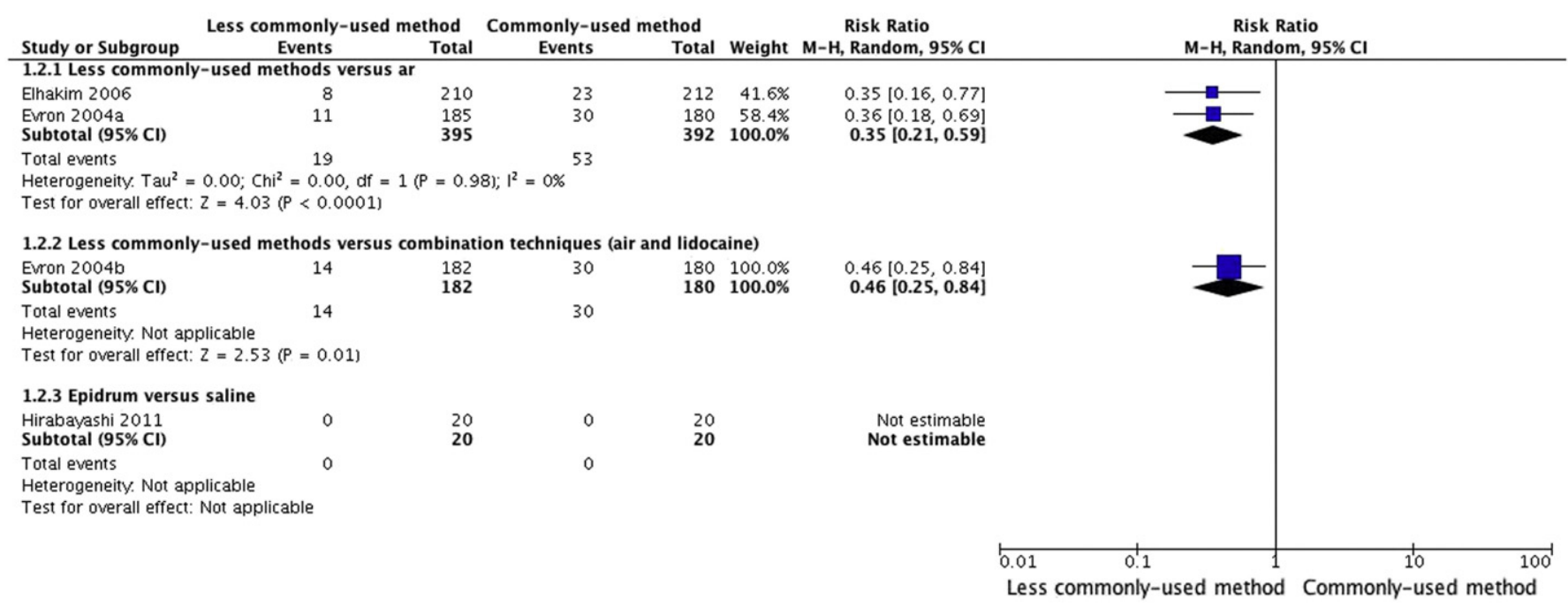

Fig. 4. Meta-analysis of accidental intravascular catheter placement and/or accidental subarachnoid catheter placement.

of bias decreased confidence in our estimates, including: lack of blinding of patients, health care providers and outcome adjudicators in a number of studies, lack of allocation concealment, and some inconsistency in two of the meta-analyses that may represent substantial heterogeneity (Figs. 3 and 6). There was no difference related to side effects comparing the alternative and conventional methods in the RCTs.

"To appropriately identify the epidural space, it is necessary to have adequate knowledge of the relevant anatomy. Use of air or saline has been controversial and widely variable amongst anaesthesiologists" [2]. However, "the inability to locate the epidural space (defined as inability to identify the epidural space and/or unintentional dural puncture by the epidural needle) also appears to be dependent on the amount of training the anaesthesiologist has undergone" [2]. Therefore, independent of the method used in the LOR technique, the identification of alternative potential techniques to access the epidural space may be necessary to avoid unnecessary complications such as paraesthesias, air venous embolisms, neurological complications, accidental punctures of the dura mater, total subarachnoid blocks, and pneumoencephaly.

Another variable which might influence the results independent of the technique used in the LOR technique is the "correlation between volume of anaesthetic injected by the epidural needle and successful catheter passage subsequently" [2]. Earlier studies have proven that "a large volume of local anaesthetics through the needle facilitates catheter placement, decreasing the chance of accidental intravascular or subarachnoid catheter placement" [2,52,53].

Finally, only one included study [48] described severe morbidities such as pneumonia, poor oxygenation and myocardial infarction; these outcomes are unlikely to be correlated with the application of either of the two LOR technique methods.

\subsection{Strengths and limitations}

Strengths of our review include: a comprehensive literature search; assessment of eligibility, risk of bias, and data abstraction independently and in duplicate; assessment of risk of bias; sensitivity analysis addressing loss to follow-up; and use of the GRADE approach in rating the certainty of evidence for each outcome.

Limitations of our study include only eight studies being eligible despite a comprehensive search of four databases, prominent journals and the reference lists of all relevant primary studies and systematic reviews. Methodological quality was generally deemed to be unclear or low risk of bias across all included studies. The limited number of eligible studies prevented subgroup analyses from being conducted based on the characteristics of participants (e.g., pregnant vs. non-pregnant patients); the criteria for a minimum of six eligible studies, with at least three for each sub-group, was not met for any potential analysis.

Another limitation of this review is the fact that most data is focused on the use of epidrum, with varying patient populations, and data also comes from the subgroup analyses that included only one study. In considering the results of these studies together, it is important to consider that pregnant patients have a greater chance of epidural venous bleeding, dural puncture and headache than non-pregnant patients. Furthermore, orthopedic patients also differ in their likelihood of experiencing successful epidural insertion and complications.

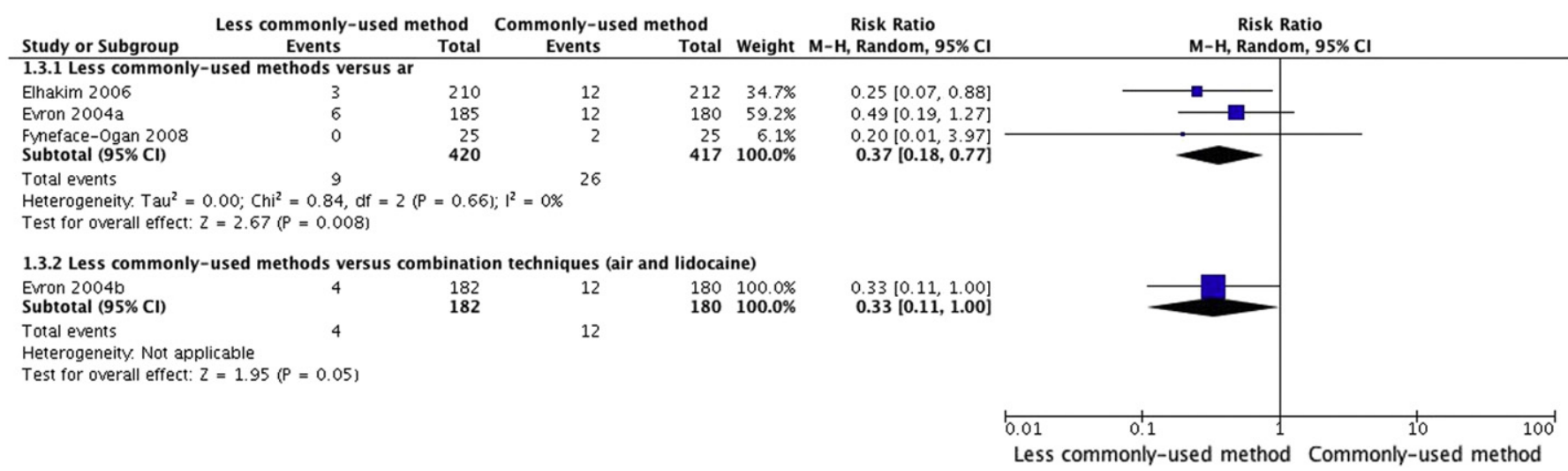




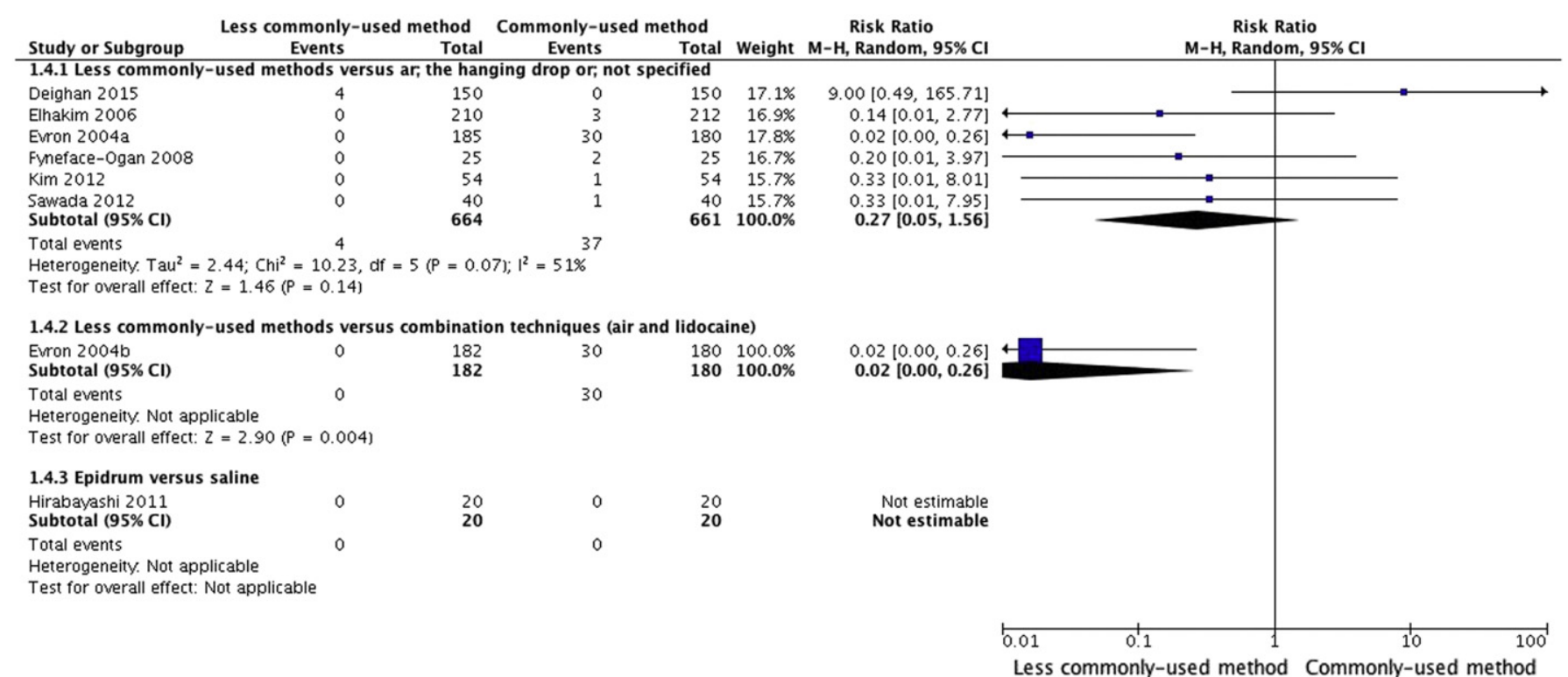

Fig. 6. Meta-analysis of inadvertent dural puncture.

One could argue that these limitations make the pooling of results we have undertaken inadvisable. On the other hand, the pooling does highlight the moderate-quality evidence of less commonly-used methods on the reduction in inability to locate the epidural space, a possibility that, until definitively refuted by randomized trials, needs consideration in policy debates regarding the loss of resistance technique for identification of the epidural space.

Finally, another limitation of this review is the potential for heterogeneity as the less commonly-used methods compared differ in terms of techniques. It is possible that analyzing these methods separately would have greater benefit. However, the fact of having insufficient number of included studies did not allow the complete statistical analysis that we had planned.

Although this review presents several limitations, the issue is whether one should dismiss these results entirely, or consider them bearing in mind the limitations. The latter represent our view of the matter.

\subsection{Relation to prior work}

The previous Cochrane review [2] comparing conventional methods in the LOR technique concluded "low-quality evidence shows that results do not differ between air and saline when the LOR technique is used to locate the epidural space" [2]. However, findings were limited by a trivial sample size and lack of standardization of results across studies, making a meta-analysis difficult to conduct.

\subsection{Implications}

Moderate-quality evidence shows that less commonly-used methods such as epidrum, lidocaine, acoustic devices, or modified Macintosh epidural balloon are more efficacious compared to more commonly-used methods (air, saline, or both) in terms of the LOR technique for identification of the epidural space. With regards to safety-related outcomes, moderate-quality evidence demonstrates that complications are relatively equal between both approaches.

\section{Financial support and sponsorship}

The authors have declared that no competing interests exist. This work was supported by the São Paulo Research Foundation (FAPESP) [grant \# 2013/12368-2]. Regina El Dib received a Brazilian Research Council (CNPq) scholarship (\#310953/2015-4).

\section{Conflicts of interest}

The authors report no conflicts of interest. The funding agency played no role in the conduct of the research or preparation of the manuscript.

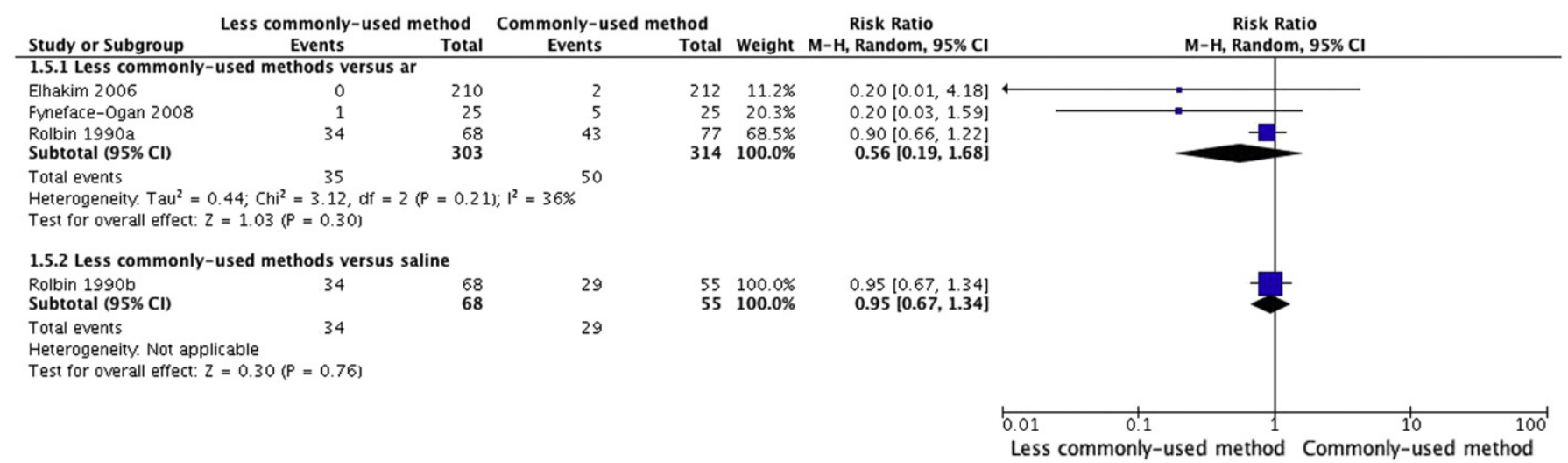




\section{Authors' contributions}

Larissa Pierri Carvalho (LPC), Arnav Agarwal (AA), Flávio T Kashiwagi (FTK), Ione Corrêa (IC), José Eduardo G Pereira (JEGP), Regina El Dib (RED).

Author Contributions: conceptualization: RED.

Author Contributions: methodology: JEGP RED.

Author Contributions: software: LPC RED.

Author Contributions: validation: LPC JEGP RED.

Author Contributions: formal analysis: LPC JEGP RED.

Author Contributions: investigation: LPC FTK JEGP RED.

Author Contributions: resources: IC.

Author Contributions: data curation: LPC FTK JEGP RED.
Author Contributions: writing (original draft preparation): LPC AA IC JEGP RED.

Author Contributions: writing (review and editing): LPC AA FTK IC JEGP RED.

Author Contributions: visualization: JEGP RED.

Author Contributions: supervision: JEGP RED.

Author Contributions: project administration: RED.

Author Contributions: funding acquisition:

\section{Acknowledgments}

We also would like to thank Dr. Hyderabayshi for helping us with the data extraction of the included Japanese paper.

\section{Appendix A}

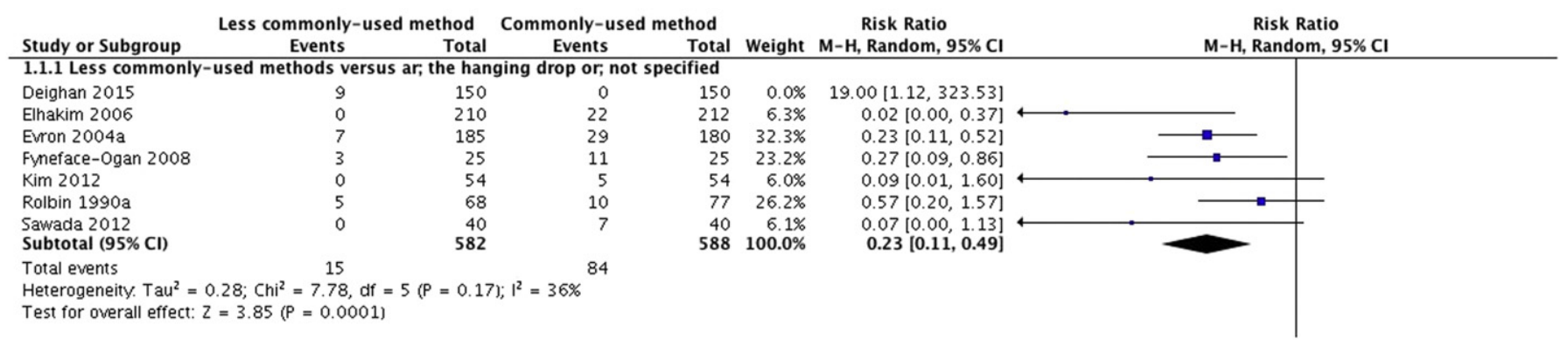

Appendix Fig. 1. Sensitivity analysis of inability to locate the epidural space.

\section{References}

[1] Cowan M, Moore EW. A survey of epidural technique and accidental dural puncture rates among obstetric anaesthetists. Int J Obstet Anesth 2001;10:11-6.

[2] Antibas PL, do Nascimento Junior P, Braz LG, Vitor Pereira Doles J, Módolo NS, El Dib R. Air versus saline in the loss of resistance technique for identification of the epidural space. Cochrane Database Syst Rev 2014;7:CD008938.

[3] Scott DB. Identification of the epidural space: loss of resistance to air or saline? Reg Anesth 1997:22:1-2.

[4] Howell TK, Prosser DP, Harmer M. A change in resistance? A survey of epidural practice among obstetric anaesthetists. Anaesthesia 1998;53:238-43.

[5] Naulty JS, Ostheimer GW, Datta S, et al. Incidence of venous air embolism during epidural catheter insertion. Anesthesiology 1982;57:410-2.

[6] Russell R. Loss of resistance to saline is better than air for obstetric epidurals. Int J Obstet Anesth 2001;10:302-6.

[7] Deam RK, Scott DA. Neurological damage resulting from extracorporeal shock wave lithotripsy when air is used to locate the epidural space. Anaesth Intensive Care 1993;21:455-7.

[8] Gleeson CM, Reynolds F. Accidental dural puncture rates in UK obstetric practice. Int J Obstet Anesth 1998;7:242-6.

[9] Huffnagle SL, Norris MC, Arkoosh VA, et al. The influence of epidural needle bevel orientation on spread of sensory blockade in the laboring parturient. Anesth Analg 1998;87:326-30.

[10] Laviola S, Kirvela M, Spoto MR, et al. Pneumocephalus with intense headache and unilateral pupillary dilatation after acci- dental dural puncture during epidural anesthesia for cesarean section. Anesth Analg 1999;88:582-3.

[11] Chadwick HS. An analysis of obstetric anesthesia cases from the American Society of Anesthesiologists closed claims project da- tabase. Int J Obstet Anesth 1996;5: 258-63.

[12] Dalens B, Bazin JE, Haberer JP. Epidural bubbles as a cause of incomplete analgesia during epidural anesthesia. Anesth Analg 1987;66:679-83.

[13] Kuczkowski M, Benumof JL. Images in anesthesia: headache caused by pneumocephalus following inadvertent dural puncture during epidural space identification: is it time to abandon the loss of resistance to air technique? Can J Anesth 2003;50:159-60.

[14] Nay PG, Milaszkiewicz R, Jothilingam S. Extradural air as a cause of paraplegia following lumbar analgesia. Anaesthesia 1993;48:402-4.

[15] Iwama H. Injection volume of saline with loss of resistance method may affect the spread of epidural anesthesia. Anesthesiology 1997;86:507-8.

[16] Okutomi T, Hoka S. Epidural saline solution prior to local anaesthetic produces differential nerve block. Can J Anaesth 1998;45:1091-3.
[17] Baraka A. Identification of the thoracic epidural space by the running infusion drip technique. Can J Anaesth 2001;48:935-6.

[18] Evans JM. The Oxford epidural space detector. Lancet 1982;2:1433-4.

[19] Macintosh RR. Extradural space indicator. BMJ 1953;14:398.

[20] Sawada A, Kii N, Yoshikawa Y, Yamakage M. Epidrum ${ }^{\circledR}$ : a new device to identify the epidural space with an epidural Tuohy needle. J Anesth 2012;26:292-5.

[21] Tielens LK, Bruhn J, Vogt M, van Geffen GJ, Scheffer GJ. The Episure Autodetect syringe, a loss-of-resistance technique for locating the epidural space, used in pediatric patients. Paediatr Anaesth 2013;23:747-50.

[22] Gutierrez A. Anestesia Metamerica peridural. Rev Cir Buenos Aires 1932;12:665-85

[23] Shah JL. Identification of the epidural space. Br J Hosp Med 1991;46:60-3.

[24] Jacob S, Tierney E. A dual technique for identification of the epidural space. Anaesthesia 1997;52:141-3.

[25] Segal S, Arendt KW. A retrospective effectiveness study of loss of resistance to air or saline for identification of the epidural space. Anesth Analg 2010;110:558-63.

[26] Lechner TJ, van Wijk MG, Maas AJ, van Dorsten FR, Drost RA, Langenberg CJ, et al Clinical results with the acoustic puncture assist device, a new acoustic device to identify the epidural space. Anesth Analg 2003;96(4):1183-7.

[27] Lechner TJM, van Wijk MGF, Maas AJJ. Clinical results with a new acoustic device to identify the epidural space. Anaesthesia 2002;57:1-5.

[28] Evron S, Sessler D, Sadan O, Boaz M, Glezerman M, Ezri T. Identification of the epidural space: loss of resistance with air, lidocaine, or the combination of air and lidocaine. Anesth Analg 2004;99:245-50.

[29] Ash KM, Cannon JE, Biehl DR. Pneumocephalus following attempted epidural anaesthesia. Can J Anaesth 1991;38:772-4.

[30] Carter MI. Cervical surgical emphysema following extradural analgesia. Anaesthesia 1984;39:1115-6.

[31] Gonzalez-Carrasco FJ, Aquilar JL, Llubia C, Nogués S, Vidal-López F. Pneumocephalus after accidental dural puncture during epidural anaesthesia. Reg Anesth 1993;18: 193-5.

[32] Hiromi S, Kiyoshi T, Masayoshi Y, Megumi O, Kyoko Y, Hisatoshi O. Complications resulting from the loss of resistance technique with air. J Clin Anesth 1999;23: 1427-30.

[33] Bromage PR. Unblocked segments in epidural analgesia for relief of pain in labour. $\mathrm{Br}$ J Anaesth 1972;44:676-9.

[34] Stride PC, Cooper GM. Dural taps revisited: a 20-year survey from Birmingham maternity hospital. Anaesthesia 1993;48:247-55.

[35] Higgins JPT, Green S. Cochrane handbook for systematic reviews of interventions 5.1.0. United Kingdom and Australia: The Cochrane Collaboration; 2011.

[36] Moher D, Liberati A, Tetzlaff J, Altman DG, The PRISMA Group. Preferred reporting items for systematic reviews and meta-analyses: the PRISMA statement. PLoS Med 2009;6:e1000097. 
[37] Higgins JP, Altman DG, Gøtzsche PC, Jüni P, Moher D, Oxman AD, et al. The Cochrane Collaboration's tool for assessing risk of bias in randomised trials. BMJ 2011;343: d5928.

[38] Guyatt GH, Busse JW. Modification of Cochrane tool to assess risk of bias in randomized trials. DistillerSR; 2016[Available: http://distillercer.com/resources/].

[39] Guyatt GH, Oxman AD, Vist GE, Kunz R, Falck-Ytter Y, Alonso-Coello P, et al. GRADE: an emerging consensus on rating quality of evidence and strength of recommendations. BMJ 2008:336:924-6.

[40] Guyatt GH, Oxman AD, Vist G, Kunz R, Brozek J, Alonso-Coello P, et al. GRADE guidelines: 4. Rating the quality of evidence-study limitations (risk of bias). J Clin Epidemiol 2011;64:407-15.

[41] Guyatt GH, Oxman AD, Kunz R, Brozek J, Alonso-Coello P, Rind D, et al. GRADE guidelines 6. Rating the quality of evidence-imprecision. J Clin Epidemiol 2011;64: 1283-93.

[42] Guyatt GH, Oxman AD, Kunz R, Woodcock J, Brozek J, Helfand M, et al. GRADE guidelines: 7. Rating the quality of evidence-inconsistency. J Clin Epidemiol 2011;64: 1294-302.

[43] Guyatt GH, Oxman AD, Kunz R, Woodcock J, Brozek J, Helfand M, et al. GRADE guidelines: 8. Rating the quality of evidence-indirectness. J Clin Epidemiol 2011;64 1303-10.

[44] Guyatt GH, Oxman AD, Montori V, Vist G, Kunz R, Brozek J, et al. GRADE guidelines: 5. Rating the quality of evidence-publication bias. J Clin Epidemiol 2011;64: 1277-82.

[45] Nordic Cochrane Centre, Cochrane Collaboration. Review manager (RevMan) version 5.3. Copenhagen: The Nordic Cochrane Centre, The Cochrane Collaboration; 2011.
[46] Deighan M, Briain DO, Shakeban H, O'Flaherty D, Abdulla H, Al-Jourany A, et al. A randomised controlled trial using the Epidrum for labour epidurals. Ir Med J 2015; 108:73-5.

[47] Kim SW, Kim YM, Kim SH, Chung MH, Choi YR, Choi EM. Comparison of loss of resistance technique between Epidrum ${ }^{\circledR}$ and conventional method for identifying the epidural space. Korean J Anesthesiol 2012;62:322-6.

[48] Hirabayashi T, Kawamata T, Sakamoto A, Ikeno S, Minemura H, Ide S, et al. Usefulness of Epidrum for teaching identification of the epidural space. Masui 2011;60: 1078-81.

[49] Fyneface-Ogan S, Mato CN. A clinical experience with epidural balloon in the localisation of the epidural space in labouring parturients. Nig Q J Hosp Med 2008; 18:166-9.

[50] Elhakim M, Metry A, El-Kabarity R, Ishak I. Epidural space identification by means of a simple acoustic device vs conventional loss of resistance to air technique. Acta Anaesth Ital 2006;57:161-73.

[51] Rolbin SH, Halpern SH, Braude BM, Kapala D, Unger R, Radhakrisnan S. Fluid through the epidural needle does not reduce complications of epidural catheter insertion. Can J Anaesth 1990;37:337-40.

[52] Cesur M, Alici HA, Erdem AF, Silbir F, Yuksek MS. Administration of local anesthetic through the epidural needle before catheter insertion improves the quality of anesthesia and reduces catheter-related complications. Anesth Analg 2005;101:1501-5.

[53] Mhyre JM, Greenfield ML, Tsen LC, Polley LS. A systematic review of randomized controlled trials that evaluate strategies to avoid epidural vein cannulation during obstetric epidural catheter placement. Anesth Analg 2009;108:1232-42. 